\title{
ESCOMBROS, ENTULHOS, VESTÍGIOS E RUÍNAS. SOBRE O INCÊNDIO DO CAMELÓDROMO NO RIO DE JANEIRO
}

\author{
Adriana Fernandes ${ }^{1}$
}

Recebido em: Novembro, 2013 Aceito em: Dezembro, 2013

Para citar este ensaio:

FERNANDES, Adriana. "Escombros, entulhos, vestígios e ruínas. Sobre o incêndio do Camelódromo no Rio de Janeiro" In: Revista Intratextos, 2013, vol 5, no1, p. 95-112. DOI: http://dx.doi.org/10.12957/intratextos.2013.11829

\footnotetext{
${ }^{1}$ Pós-doutoranda PPCIS/UERJ. Bolsista (FAPERJ/CAPES)
} 


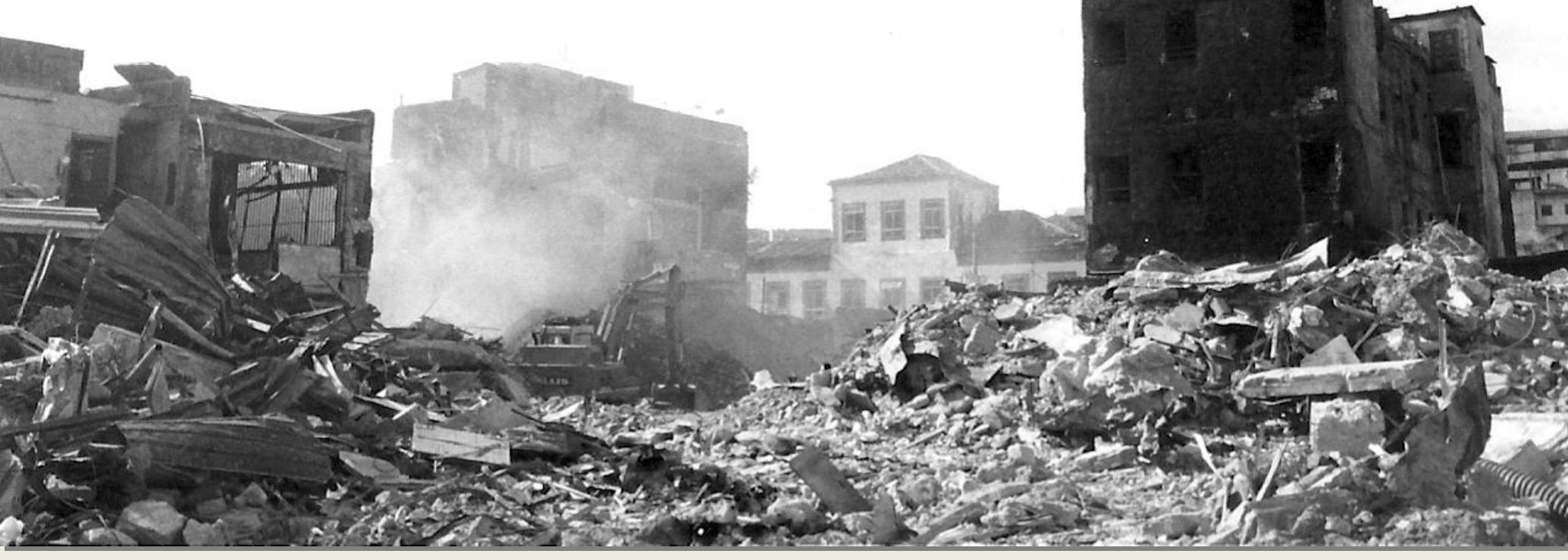




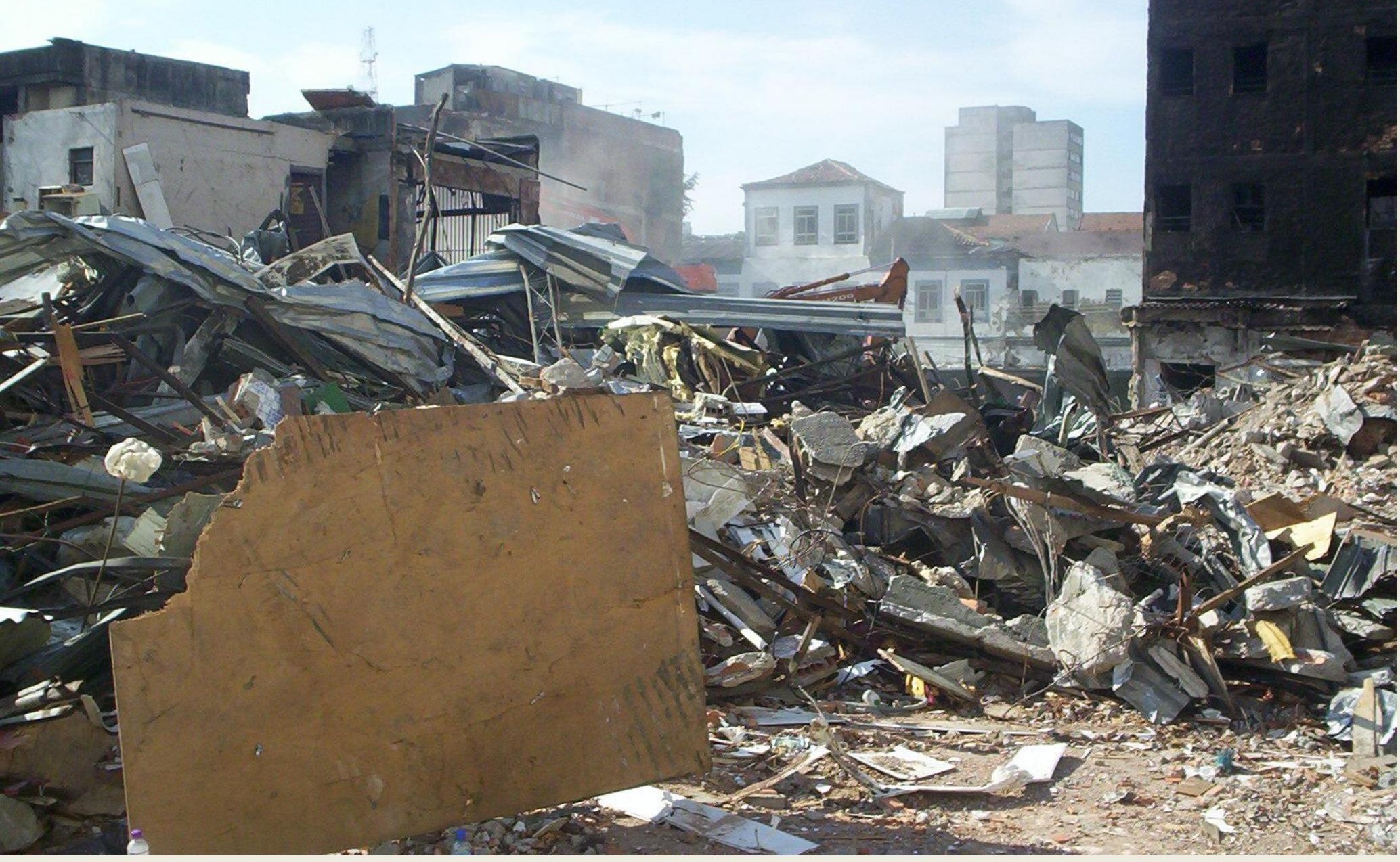




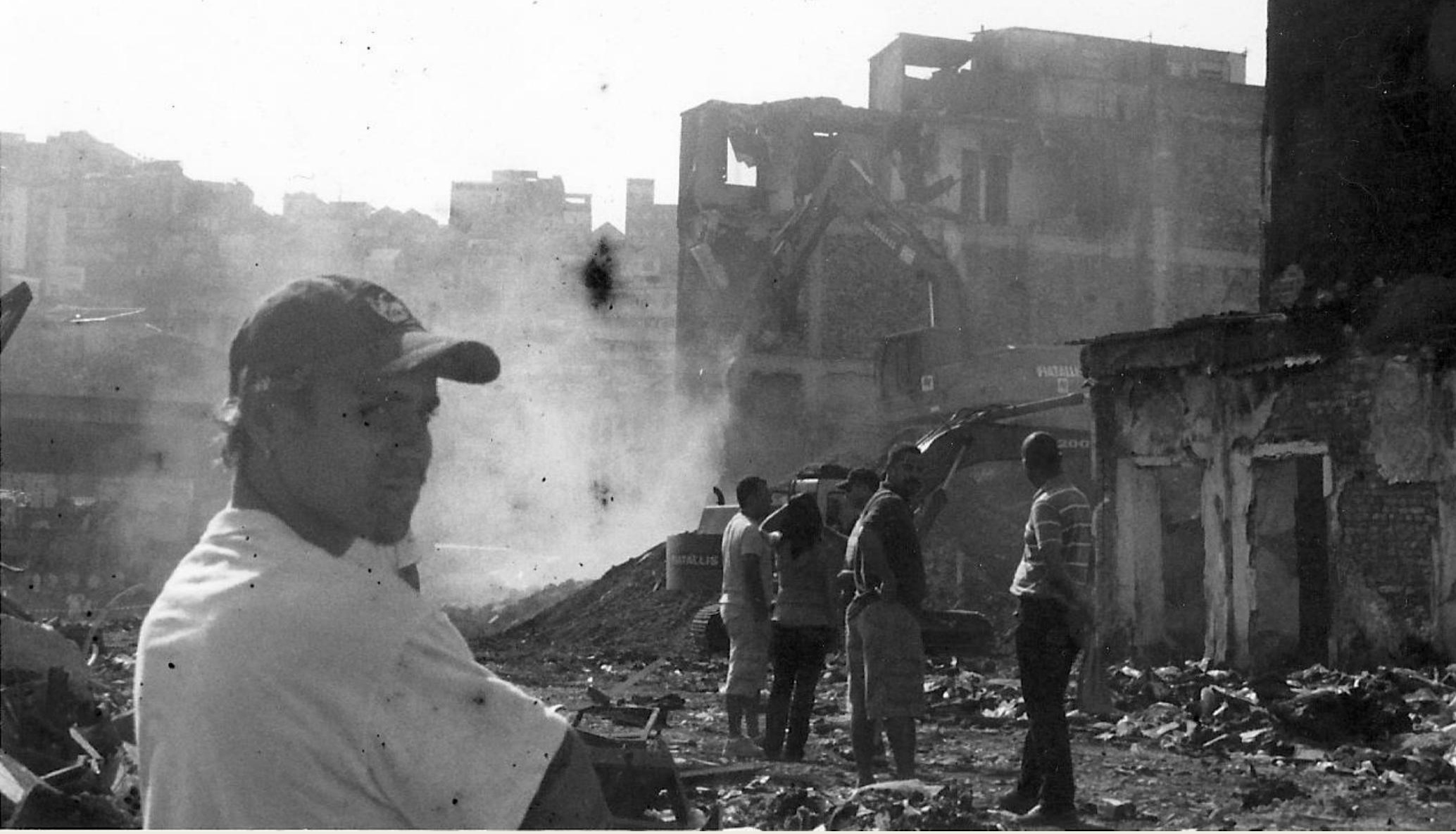




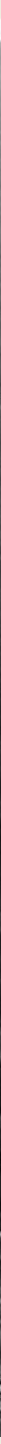




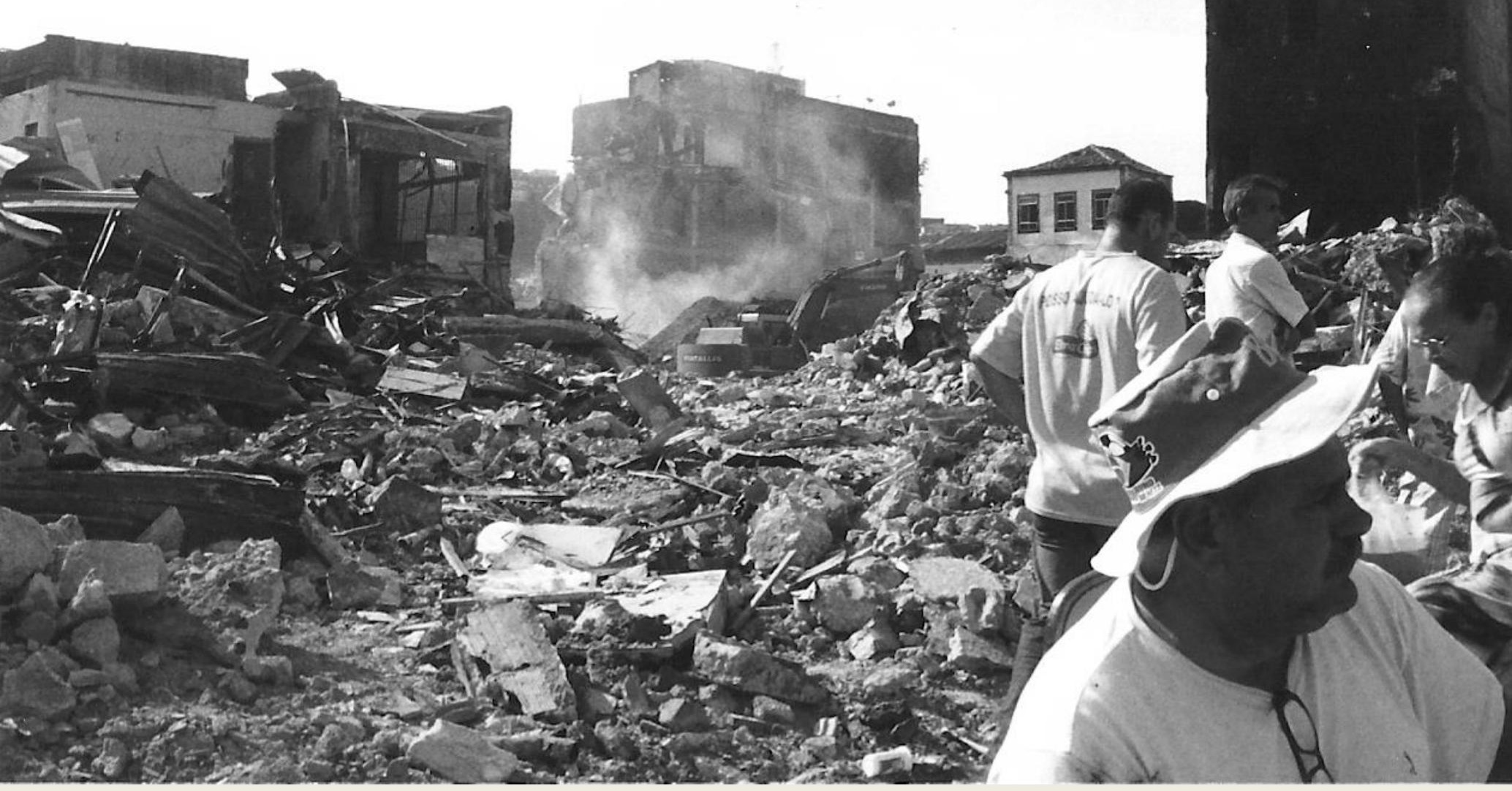




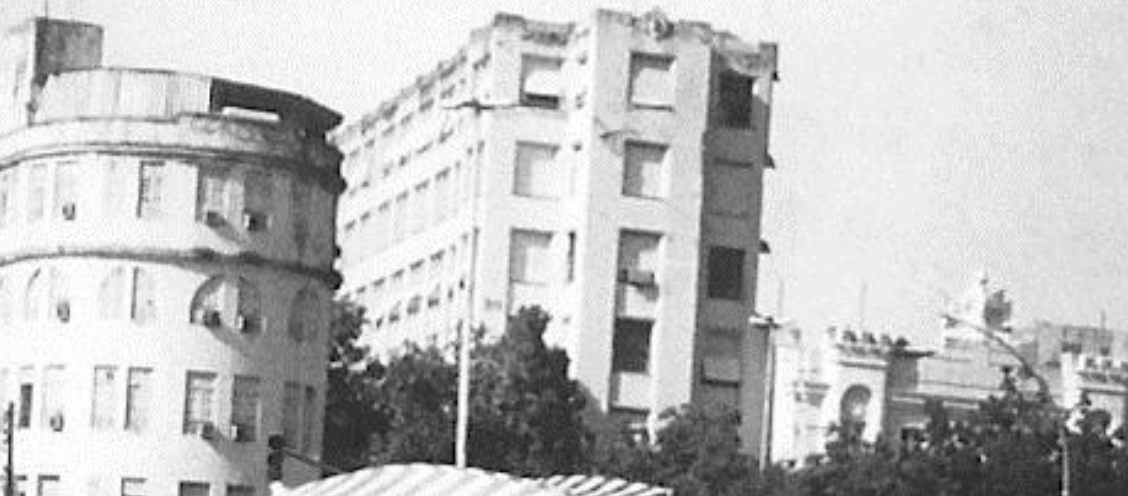

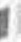

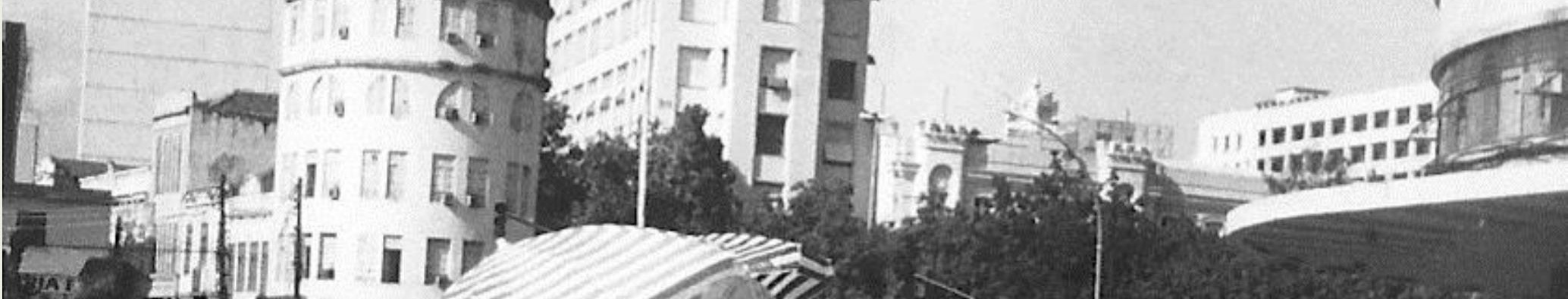

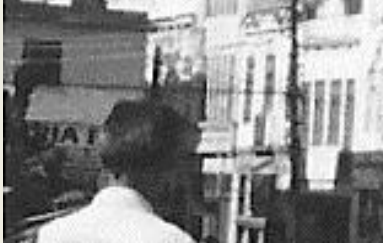

atenters

ingerion

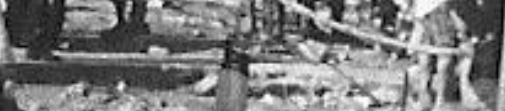

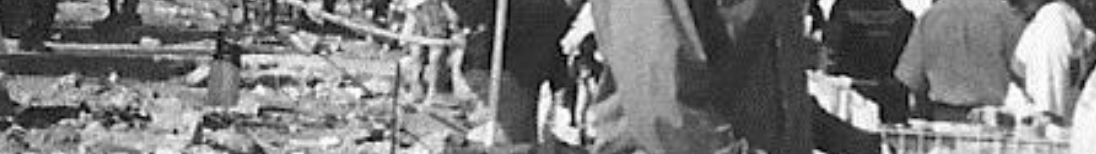

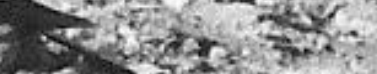

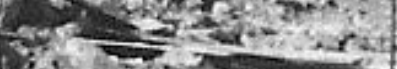

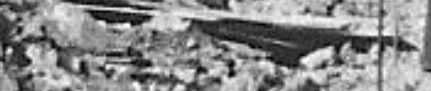

Q

ase

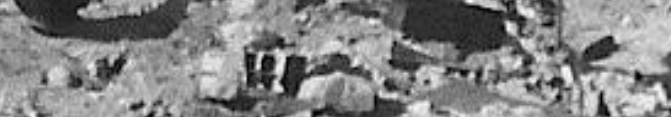

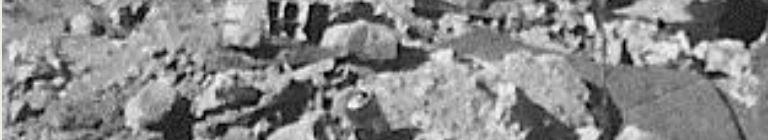
$\log ^{2} \rightarrow 1$ $+x$

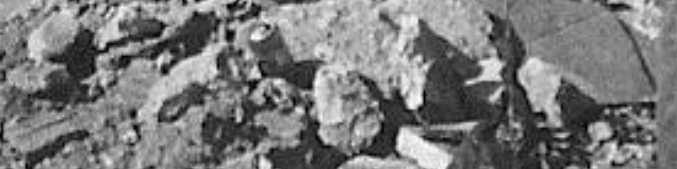

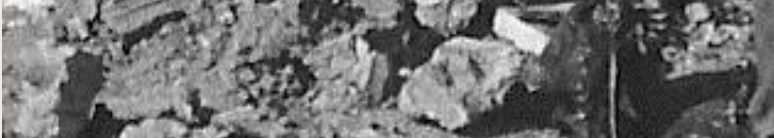

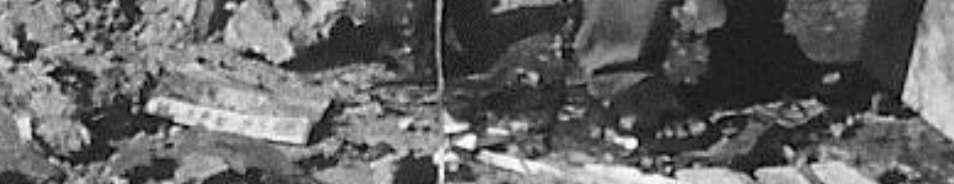

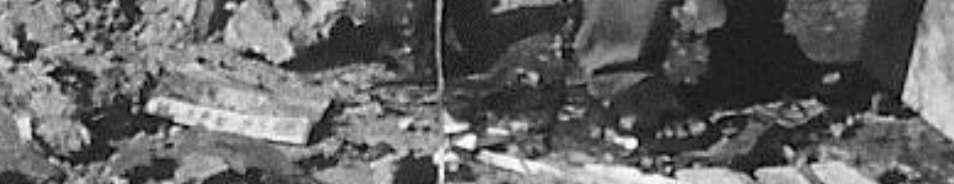

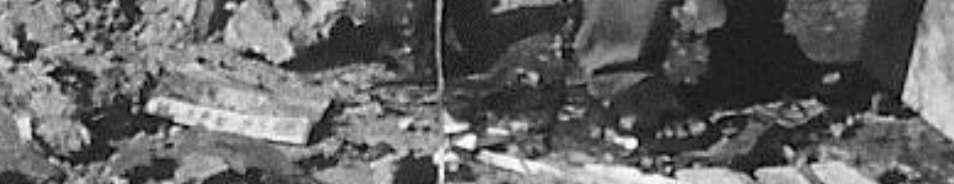
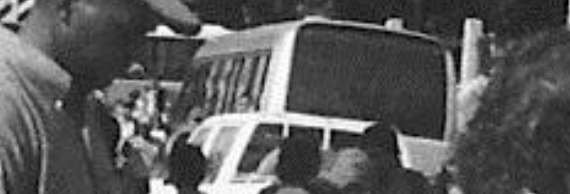

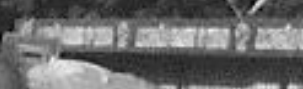

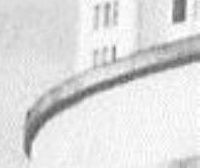

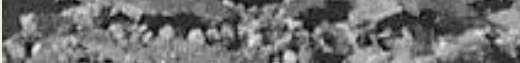

Y. ais and

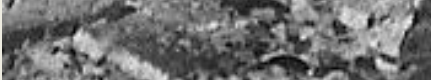

$1+5 \geqslant$

$6 x^{3}$.

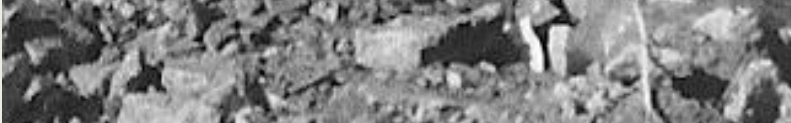

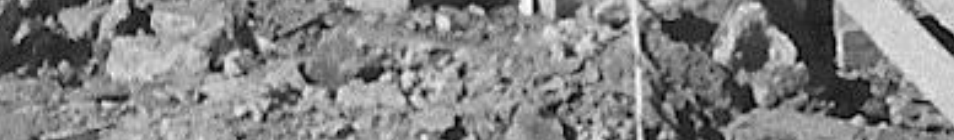
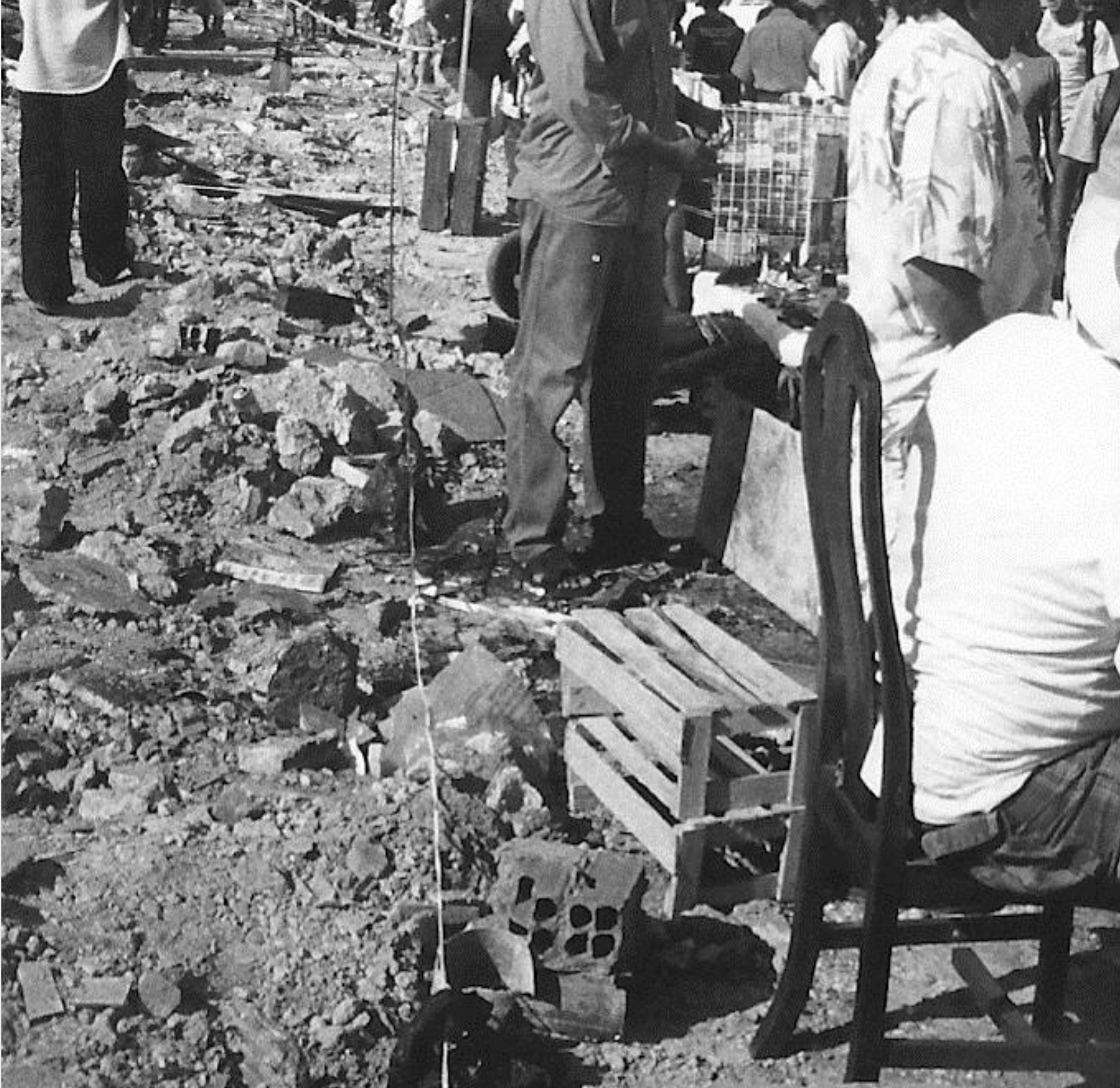

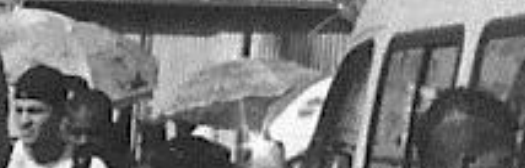

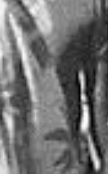




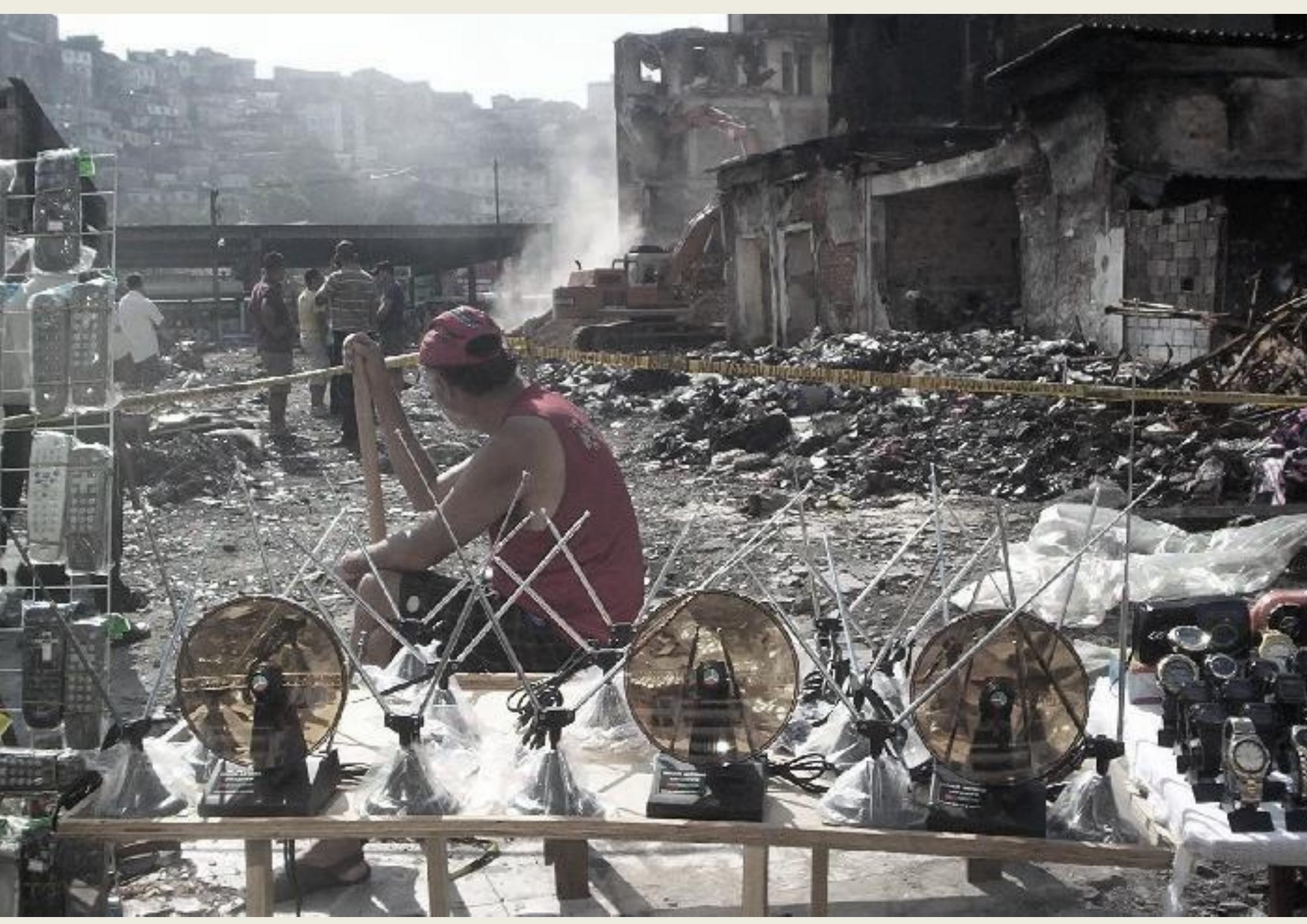




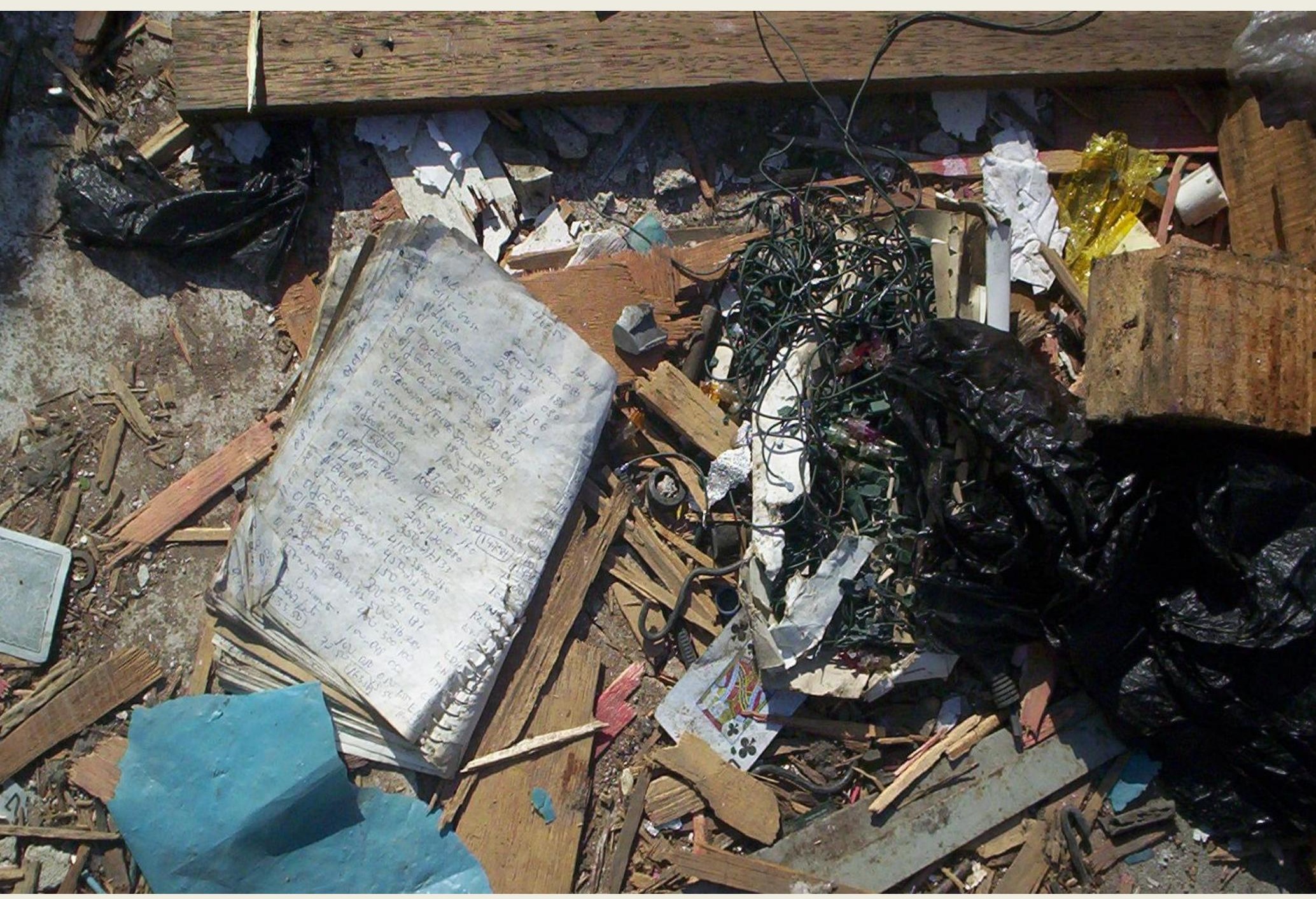




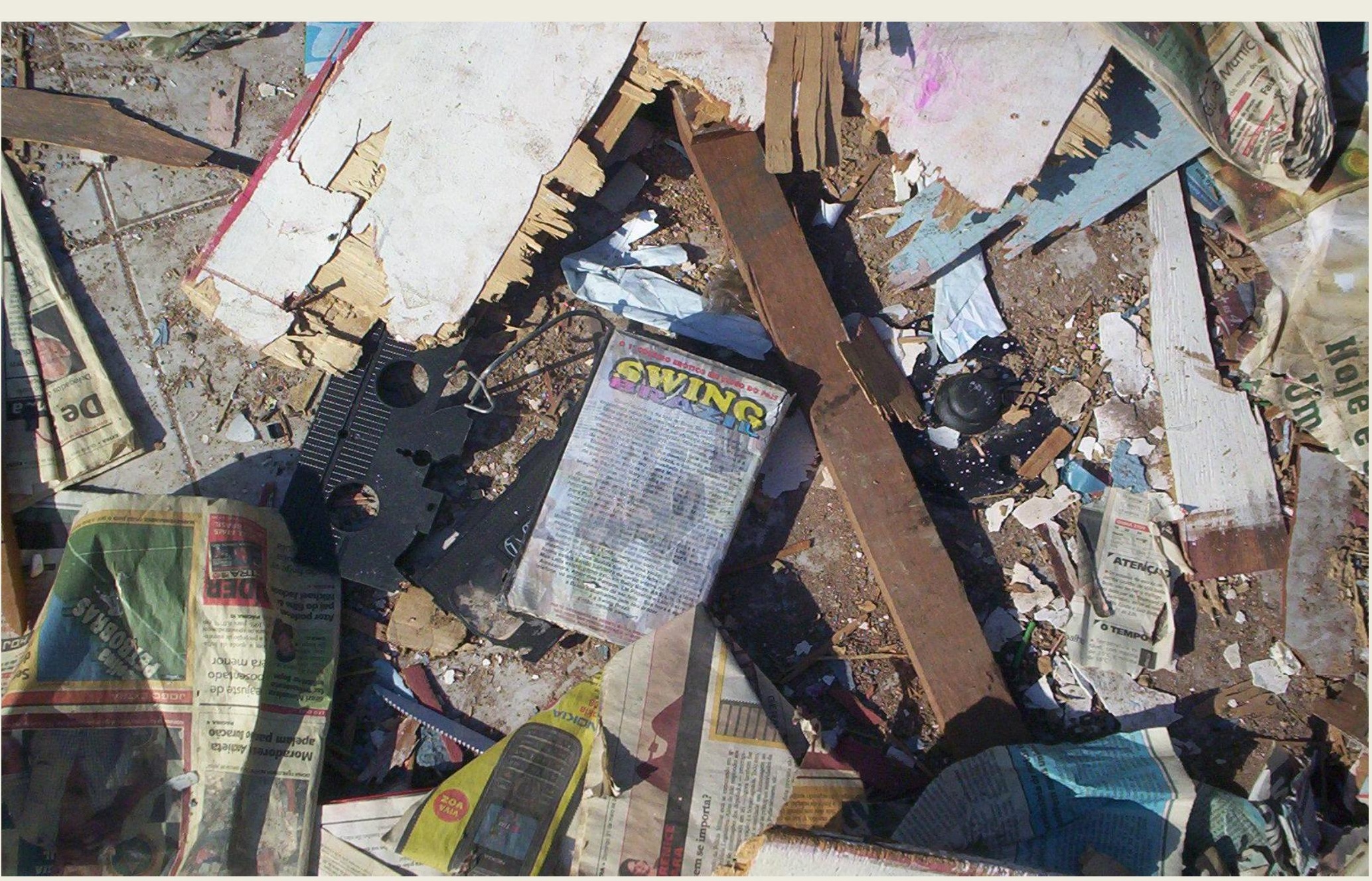




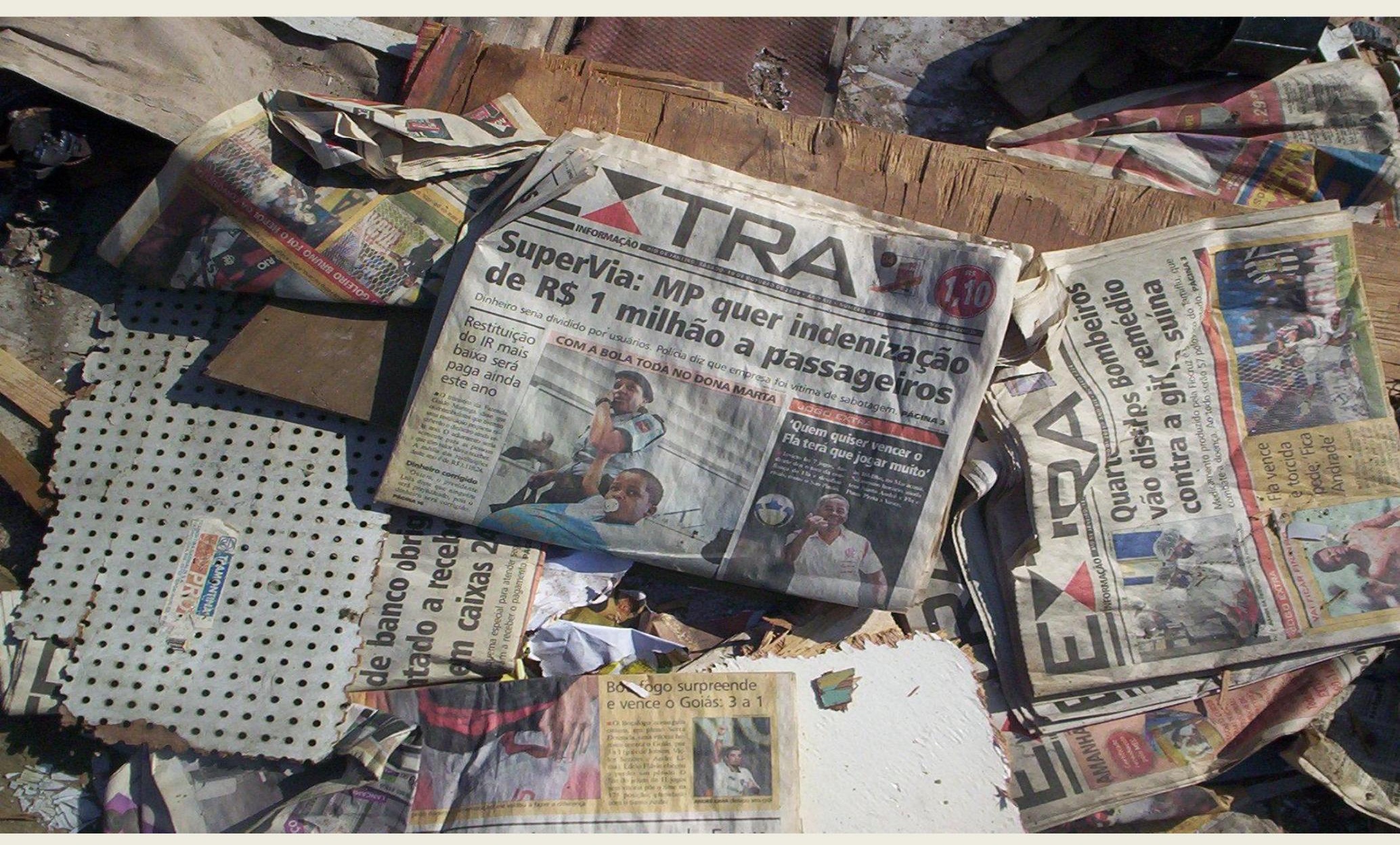




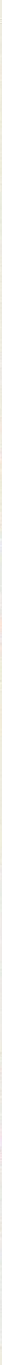




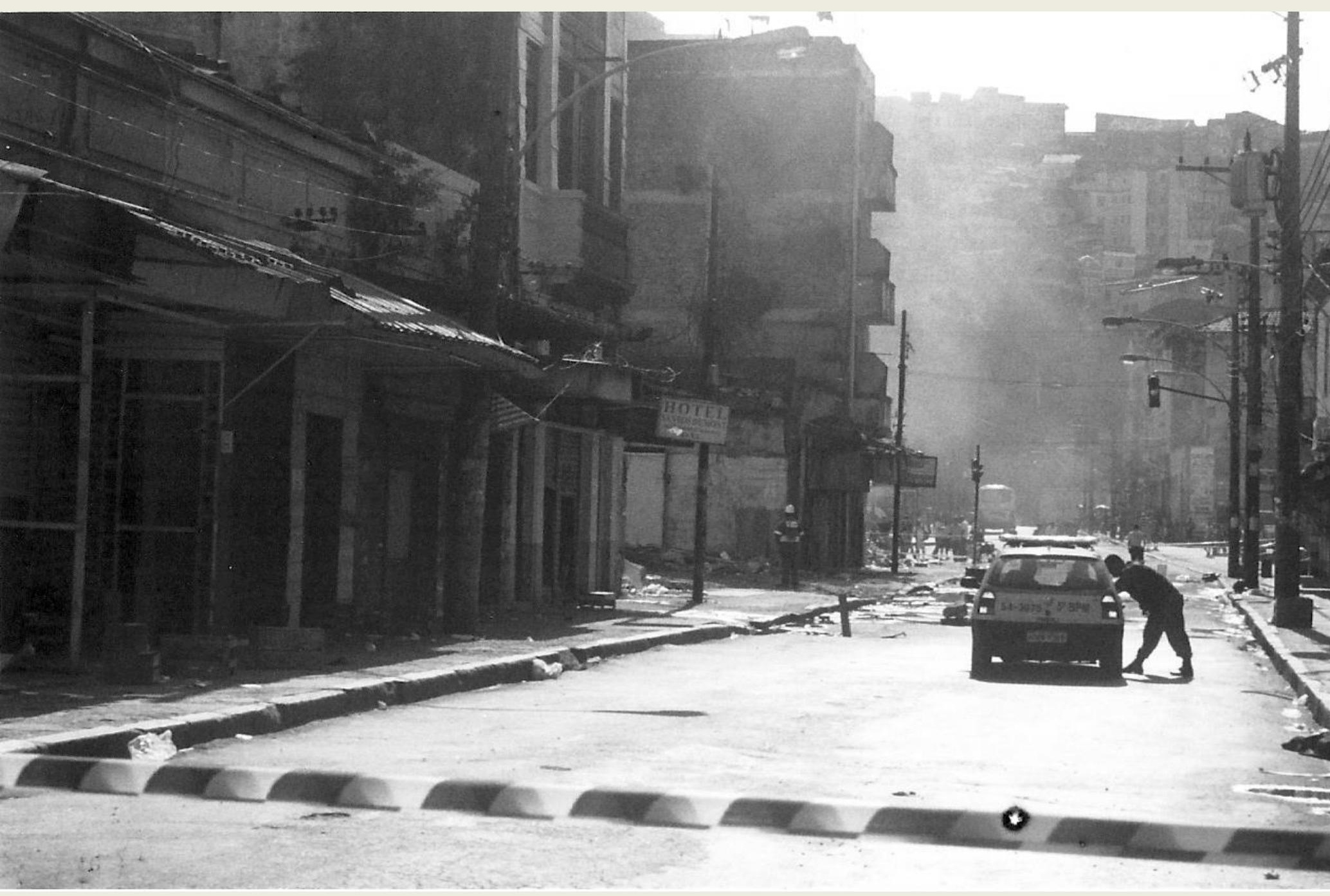




\begin{abstract}
"Construir a cidade topograficamente, dez vezes ou cem vezes, a partir de suas passagens e suas portas, seus cemitérios e bordéis, suas estações (...), assim como antigamente ela se definia por suas igrejas e seus mercados. E as figuras mais secretas, mais profundamente recônditas da cidade: assassinatos e rebeliões, os nós sangrentos no emaranhado das ruas, os leitos de amores e incêndios".
\end{abstract}

(Benjamin, W. "Paris antiga, catacumbas, demolições, declínio de Paris" em Passagens, 2006, p. 123).

Em abril de 2010 o Camelódromo, situado na parte antiga do Centro do Rio de Janeiro, foi atingido por um incêndio de proporções significativas. Informações veiculadas na imprensa contaram que o fogo surgiu de um curto-circuito ocorrido em uma padaria. Compartilhavam tal espaço: lanchonetes, bares, salões de beleza, boxes com oferta de CDs (em sua maior parte, de música gospel), relógios e celulares de origem desconhecida, carregadores de marcas ignoradas, peças para a construção civil, material elétrico, miudezas para reparos domésticos; também bancas com ofertas de secos e molhados e de frutas.

Nos bares, as máquinas de jukebox embalavam romances a qualquer hora do dia. Esses bares e lanchonetes compunham como que o coração do Camelódromo. Para chegar nele, era preciso ultrapassar corredores que, reunidos, delineavam um verdadeiro labirinto. Com alguns elementos inusitados. Esse mesmo coração (de bares e lanchonetes) não possuía toldo ou outra cobertura, como no restante do ambiente. O que produzia a impressão de uma clareira no meio de um mundão de pessoas, cheiros, sons ensurdecedores e informações. E que fervilhava no final do dia e início da noite. Isso abrangia também várias construções antigas, situadas ao redor: pequenos hotéis a baixíssimo custo (para estender os romances e outros serviços). Um lugar, portanto, enxameado ${ }^{2}$. Espaço de heterogeneidade. Caso decidíssemos acessar o terminal rodoviário (situado ao lado), seria necessário serpenteá-lo. O que era divertido de fazer, pois cruzava-se, sem problemas, com os mais diferentes tipos da vasta fauna urbana do subproletariado - não exatamente de maneira anônima (o anonimato parece não ter grassado ali).

2 "Um enxame de gafanhotos trazido pelo vento às cinco horas da tarde (...)" (Deleuze e Guattari, 1997, p.49); “(...). Enxamear parece indicar que um gesto pequeno e local, um gesto dos pequenos, pode adquirir uma enorme força." (Caiafa, 2009). 
Também funcionava no local, uma lanchonete que oferecia um açaí bastante em conta e sempre fresco. Maranhenses e paraenses davam o ar no balcão, pedindo-o sem xarope ou extrato de guaraná (algo inimaginável a maior parte dos nativos cariocas e fluminenses). Quando participei da ocupação Machado de Assis (cerca de $1 \mathrm{~km}$ do Camelódromo) - entre novembro de 2008 e janeiro de $2009^{3}$ - um dos passeios que mais apreciava era ser engolida pela turba até alcançar o balcão de tal lanchonete e consumir o generoso copo de açaí. Essa pequena pausa tornava-se ainda mais alentadora e inesquecível porque em tal espaço, uma nesga de céu se abria de maneira surpreendente, formando como um céu que nos protege.

No dia seguinte ao incêndio, a Prefeitura interditou a área e a rua lateral (importante via de acesso), distribuindo em sua extensão tratores, escavadeiras, polícia e agentes municipais. Junto com a notícia do incêndio os jornais anunciaram outros planos para o lugar. As ruínas que resistiram, seriam derrubadas e o Camelódromo seria desativado, por definitivo. Em algum quarteirão do entorno uma nova edificação se ergueria, alocando, após cadastramento, os agora "sem-boxe" (para as camadas pobres há sempre um cadastro no meio do caminho).

Jornais de grande circulação estamparam imediatamente em suas capas a maquete do futuro Mercado Popular. Nos dias que seguiram ao incêndio houve intensa movimentação por parte de quem trabalhava ou circulava por ali, além de muitos curiosos e transeuntes que queriam ver o que tinha acontecido (e assuntar o que poderia acontecer). Depois da maquete e do anúncio que todo o quarteirão seria demolido (e foi isso que efetivamente ocorreu), o pessoal que ganhava a vida no local e redondezas, começou a questionar tamanha eficácia por parte do governo. Ampliando o boato que o incêndio não teria sido acidental. Lembremos que nessa época muitas notícias divulgadas pela prefeitura e governo estadual conjeturavam a possibilidade de "revitalização" de toda essa região. Entre outras notícias havia inclusive a ideia de que o restaurante popular Garotinho (com refeições a um real) seria desativado, que o Hotel da Central (o pernoite também custava um real) seria transferido para outro bairro e que, em seu lugar, construiriam um hotel com perfil corporativo e de grande porte (os

3 Esta e outras experiências, em torno de ocupações de moradia autogestionárias na área do centro do Rio de Janeiro, formam o corpo etnográfico no qual está baseada a minha tese de doutorado Escuta Ocupação: arte do contornamento, viração e precariedade no Rio de Janeiro, defendida em 2013, pelo Programa de Pós-Graduação em Ciências Sociais/ Universidade do Estado do Rio de Janeiro. 
informes de projetos da "revitalização" usam constantemente adjetivos de teor majestoso).

Manifestações realizadas por camelôs e ambulantes da área tomaram a região nos dias seguintes, faixas foram pintadas: a preocupação era o destino incerto e a falta de informações que pudessem se valer; contribuía para o quadro as notícias desencontradas trazidas pela grande mídia. A polícia fincou pé nas ruas, viaturas da corporação fizeram rondas em algumas vias e interditaram outras. O hotel Santos Dumont, na Bento Ribeiro, rua que margeava o Camelódromo, restava mais desolado, confirmando-se seu destino e de outros prédios próximos: se tornariam escombros num curtíssimo prazo.

Esses escombros, entulhos ou ruínas do Camelódromo, quatro anos depois, se multiplicaram por toda a cidade ${ }^{4}$. As fotos deste ensaio foram escolhidas na medida em que atentam sobre a sua inscrição - como uma legenda - no Rio de Janeiro atual. E para rememorar $^{5}$ - com estes subterrâneos da cidade - os mortos próximos, e, consequentemente, atormentar os vivos

*As fotos em preto \& branco foram tiradas numa câmera analógica Nikon FM10 e as coloridas, numa máquina digital Canon G11. As imagens da Nikon FM10 contêm marcas de fungos que estavam em sua lente, mas que desconhecia até o momento da revelação dos negativos.

\section{Palavras-chave:}

Central do Brasil - Camelódromo (incêndio) - ocupação de moradia - heterogeneidade Porto Maravilha - gentrificação - Rio de Janeiro - escombros - entulhos

4 Sobre as remoções na cidade e a produção de escombros ver a tese de MAGALHÃES, 2013.

5 Cf. as pistas de Jeanne-Marie Gagnebin, a partir da obra de Walter Benjamin: “(...) a exigência da rememoração do passado não implica simplesmente a restauração do passado, mas também uma transformação do presente tal que, se o passado perdido aí for reencontrado, ele não fique o mesmo, mas seja retomado e transformado" (GAGNEBIN, 1999, pp.16-17). 


\section{Referências bibliográficas}

BENJAMIN, Walter. Passagens. (Trad. do alemão de Irene Aron; trad. do francês de Cleonice P. Barreto Mourão). Belo Horizonte/ São Paulo: Editora UFMG e Imprensa Oficial do Estado de São Paulo, 2006.

CAIAFA, Janice. Três palavras. In: Trópico (on line). Disponível em: http://p.php.uol.com.br/tropico/html/textos/2621,1.shl

DELEUZE, Gilles e GUATTARI, Felix. Mil Platôs (vol.4). (Trad. Suely Rolnik). São Paulo: Editora 34, 1997.

FERNANDES, Adriana dos Santos. Escuta Ocupação: arte do contornamento, viração e precariedade no Rio de Janeiro. Tese de doutorado. Programa de PósGraduação em Ciências Sociais/ Universidade do Estado do Rio de Janeiro, 2013.

GAGNEBIN, Jeanne-Marie. História e Narração em Walter Benjamin. São Paulo: Editora Perspectiva, 1999. Lembrar, escrever, esquecer. São Paulo: Ed. 34, 2006.

MAGALHÃES, Alexandre. Transformações no problema favela e a reatualização do problema da remoção no Rio de Janeiro. Tese de doutorado, Instituto de Estudos Sociais e Políticos, 2013. 